\title{
UNIFIED APPROACH TO REFINEMENTS OF JENSEN'S INEQUALITIES
}

\author{
J. PEČARić AND D. SVRTAN
}

\begin{abstract}
In this note we introduce a notion of $M$-dominated $k$-sample mean, where $M$ is fixed multiset, which unifies several refinements of the Jensen's inequality for any mid-convex function. The approach treats on equal basis sample means over samples with of without repetitions.
\end{abstract}

Mathematics subject classification (2000): 49J40.

Key words and phrases: Jensen's inequality, convex function.

\section{REFERENCES}

[1] D. S. Mitrinović And J. PeČARIĆ, Unified treatment of some inequalities for mixed means, Österr. Akad. Wiss. Math.-Naturwiss. Klasse. Sonderdruck aus Sitzungsb. 197 (1988), 391-397.

[2] J. PEČARIĆ AND V. VOLENEC, Interpolation of the Jensen inequality with some applications, Österr. Akad. Wiss. Math.-Naturwiss. Klasse. Sonderdruck aus Sitzungsb. 197 (1988), 463-467.

[3] J. PEČARIĆ AND D. SVRTAN, New refinements of the Jensen inequality based on samples with repetions, J. Math. Anal. Appl. 222 (1998), 365-373. 